\title{
Phytochemical Evaluation, Antimicrobial Activity, and Determination of Bioactive Components from Leaves of Aegle marmelos
}

\author{
Farina Mujeeb, Preeti Bajpai, and Neelam Pathak \\ Department of Biosciences, Integral University, Kursi Road, Lucknow 226026, India \\ Correspondence should be addressed to Neelam Pathak; pathak_neelam@yahoo.com
}

Received 29 January 2014; Revised 19 April 2014; Accepted 23 April 2014; Published 11 May 2014

Academic Editor: Paul M. Tulkens

Copyright (c) 2014 Farina Mujeeb et al. This is an open access article distributed under the Creative Commons Attribution License, which permits unrestricted use, distribution, and reproduction in any medium, provided the original work is properly cited.

The therapeutic value of Aegle marmelos Correa (Rutaceae), commonly known as "Bael," has been recognized as a component of traditional medication for the treatment of various human ailments. The plant, though, being highly explored, still lacks sufficient evidences for the best variety possessing the highest degree of medicinal values. The present study is focused on phytochemical screening of aqueous and methanolic leaf extracts of 18 varieties/accessions of A. marmelos. The crude extracts of A. marmelos revealed the presence of several biologically active phytochemicals with the highest quantity of alkaloids, flavonoids, and phenols in Pant Aparna variety. The antibacterial efficacy was investigated against pathogenic bacterial strains and the highest inhibitory activity of aqueous extract was obtained against $S$. epidermidis, whereas methanolic extract was found to be most potent against $S$. aureus at $40 \mathrm{mg} / \mathrm{mL}$ concentration. However, in aqueous : ethanol, the best results were observed against E. aerogenes followed by $K$. pneumonia and S. epidermidis. The MIC of aqueous and methanol extract of Aegle marmelos ranged from $10 \mathrm{mg} / \mathrm{mL}$ to $40 \mathrm{mg} / \mathrm{mL}$ whereas in aqueous : ethanol it ranged between $40 \mathrm{mg} / \mathrm{mL}$ and $160 \mathrm{mg} / \mathrm{mL}$. The GC-MS analysis revealed the presence of many bioactive compounds such as flavonoids, alcohols, aldehydes, aromatic compounds, fatty acid methyl esters, terpenoids, phenolics, and steroids that can be postulated for antibacterial activity.

\section{Introduction}

India is widely known as the botanical garden of the world since it is the largest producer of medicinal herbs [1]. Medicinal plants act as an indigenous source of new compounds possessing therapeutic value and can also be used in drug development. $80 \%$ of the population of developing countries depend on traditional medicines, mostly natural plant products, for their primary health care needs as estimated by WHO [2]. Because of the growing recognition of natural products the demand for medicinal plants has been increasing all over the world. They have minimal toxicity, are cost effective and pharmacologically active, and provide an easy remedy for many human ailments as compared to the synthetic drugs which are a subject of adulteration and side effects [3]. The alarming increase in the rate of infection by antibiotic-resistant microorganisms has urged scientists to search for compounds which have potential antimicrobial activity [4]. The ability to synthesize compounds by secondary metabolism possessing antimicrobial potential makes plants an invaluable source of pharmaceutical and therapeutic products [5]. The effectiveness of plant extracts on microorganism has been studied worldwide [6-9].

Bael (Aegle marmelos) has been known to be one of the most important medicinal plants of India since Charak (1500 B.C) [10]. More than 100 phytochemical compounds have been isolated from various parts of the plant, namely phenols, flavonoids, alkaloids, cardiac glycosides, saponins, terpenoids, steroids, and tannins. These compounds are well known to possess biological and pharmacological activity against various chronic diseases such as cancer and cardiovascular and gastrointestinal disorders [11-14]. Antioxidant, antiulcer, antidiabetic, anticancer, antihyperlipidaemic, antiinflammatory, antimicrobial, antispermatogenic effects have also been reported on various animal models by the crude extracts of this plant [14-22]. Every part of Aegle marmelos 
plant such as its fruits, stem, bark, and leaves possesses medicinal property and is used for treating various eye and skin infections [23]. Leaf is considered to be one of the highest accumulatory parts of the plant containing bioactive compounds which are synthesized as secondary metabolites [24]. The present study was, therefore, aimed at evaluating the phytochemical potential and antibacterial activity of Aegle marmelos aqueous and methanolic leaf extracts.

\section{Materials and Methods}

2.1. Collection and Identification of Plant Material. The fresh leaves of Aegle marmelos from 18 varieties/accessions were collected from the orchard of Narendra Deva University of Agriculture and Technology, Kumarganj, Faizabad, India. The taxonomy of the plant was authenticated.

2.2. Extract Preparation. The leaves of the plant were properly washed in tap water and rinsed in distilled water. The rinsed leaves were hot air-dried for 3 days. The dried leaves of each plant were pulverized using pestle mortar to obtain a powdered form which was stored in airtight glass containers at $4^{\circ} \mathrm{C}$ until used. $10 \mathrm{~g}$ of powdered sample was soaked in distilled water and methanol $(200 \mathrm{~mL}$ and $100 \mathrm{~mL})$ separately for $12 \mathrm{hrs}$ at room temperature. The extracts were then filtered and concentrated to a final volume of $50 \mathrm{~mL}$ and subjected to phytochemical analysis.

For antibacterial screening the leaf extracts were prepared from Pant Aparna variety by following the protocol of Harborne [25] in Soxhlet apparatus using $180 \mathrm{~mL}$ of distilled water and methanol. For aqueous: ethanol, $50: 130$ volume of distilled water and ethanol were taken. Every extraction was carried out for $24 \mathrm{hrs}$ and the extract was then dried, weighed, and stored in refrigerator at $4^{\circ} \mathrm{C}$.

2.3. Phytochemical Analysis. Qualitative phytochemical analyses of both the extracts were performed by following the protocol of Adetuyi and Popoola [26], Trease and Evans [27], and Sofowora [28].

Tannins. $200 \mathrm{mg}$ of plant material was boiled in $10 \mathrm{~mL}$ distilled water and few drops of $\mathrm{FeCl}_{3}$ were added to the filtrate; a blue-black precipitate indicated the presence of Tannins.

Alkaloids. $200 \mathrm{mg}$ plant material was boiled in $10 \mathrm{~mL}$ methanol and filtered. $1 \% \mathrm{HCl}$ was added followed by 6 drops of Dragendorff reagent, and brownish-red precipitate was taken as evidence for the presence of alkaloids.

Saponins (Frothing test). $5 \mathrm{~mL}$ distilled water was added to $200 \mathrm{mg}$ plant material. $0.5 \mathrm{~mL}$ filtrate was diluted to $5 \mathrm{~mL}$ with distilled water and shaken vigorously for 2 minutes. Formation of stable foam indicates the presence of saponins.

Cardiac Glycosides (Keller-Kiliani test). $2 \mathrm{~mL}$ filtrate was treated with $1 \mathrm{~mL}$ glacial acetic acid containing few drops of $\mathrm{FeCl}_{3}$. Conc. $\mathrm{H}_{2} \mathrm{SO}_{4}$ was added to the above mixture giving green-blue colour depicting the positive results for presence of cardiac glycosides.

Steroids (Liebermann-Burchard reaction). $200 \mathrm{mg}$ plant material was added in $10 \mathrm{~mL}$ chloroform. Acetic anhydride was added in the ratio of $1: 1$ which resulted into the formation of blue-green ring pointing towards the presence of steroids.

Terpenoids (Salkowski test). To $200 \mathrm{mg}$ plant material $2 \mathrm{~mL}$ of chloroform $\left(\mathrm{CHCl}_{3}\right)$ and $3 \mathrm{~mL}$ of concentrated sulphuric acid $\left(\mathrm{H}_{2} \mathrm{SO}_{4}\right)$ were carefully added. A reddish brown colouration signified the presence of terpenoids.

Flavonoids. To the aqueous filtrate $5 \mathrm{~mL}$ of dilute ammonia solution was added, followed by concentrated $\mathrm{H}_{2} \mathrm{SO}_{4}$. A yellow colouration indicated the presence of flavonoids.

Phlobatannins. The deposition of a red precipitate denoted the presence of phlobatannins when $200 \mathrm{mg}$ of plant material was dissolved in $10 \mathrm{~mL}$ of aqueous extract and few drops of $1 \%$ $\mathrm{HCl}$ were added in the boiling tube.

Anthraquinones. $500 \mathrm{mg}$ of dried plant leaves were boiled in $10 \% \mathrm{HCl}$ for 5 mins and filtrate was allowed to cool. Equal volume of $\mathrm{CHCl}_{3}$ with few drops of $10 \% \mathrm{NH}_{3}$ was added to $2 \mathrm{~mL}$ filtrate. The formation of rose-pink colour implies the presence of Anthraquinones.

Reducing Sugars. To the $10 \mathrm{~mL}$ of aqueous extract a few drops of Fehling's solution A and B were added; an orange red precipitate suggests the presence of reducing sugars.

\subsection{Quantitative Estimation of Phytochemicals}

2.4.1. Determination of Alkaloids. Alkaloids content was measured by following the protocol described by Harborne [29]. A suspension was prepared by dispersing $5 \mathrm{gm}$ of the dried leaves in $10 \%$ acetic acid solution in ethanol and kept at $28^{\circ} \mathrm{C}$ for $4 \mathrm{hrs}$ which was further filtered through Whatman Number 42 . Thereafter alkaloid was precipitated by concentrating the filtrate to one quarter of its original volume and drops of conc. aqueous $\mathrm{NH}_{4} \mathrm{OH}$ were added. Finally the precipitate was washed with $1 \%$ ammonia solution and dried at $80^{\circ} \mathrm{C}$ in the oven. The content of alkaloid was calculated and expressed as $\mathrm{mg} / \mathrm{gm}$ of sample.

2.4.2. Determination of Flavonoids. The flavonoids content was also determined by Harborne [29] method. Briefly, 5 gm of leaves was boiled in $2 \mathrm{M} \mathrm{HCl}$ for 30 mins under reflux and filtered after cooling. Equal volume of ethyl acetate was then added drop wise in filtrate. The weight of precipitated flavonoid was determined and reported as $\mathrm{mg} / \mathrm{g}$.

2.4.3. Determination of Tannins. The quantitative estimation of tannins was performed by the method of Swain [30] with minor modifications in our lab. Finely powdered leaves of Aegle marmelos were kept in a beaker containing $20 \mathrm{~mL}$ of $50 \%$ methanol covered with parafilm and then heated at $80^{\circ} \mathrm{C}$ in water bath for $1 \mathrm{hr}$ with continuous stirring. The extract 
was quantitatively filtered using a double layered Whatman Number 1 filter paper and rinsed by 50\% methanol. $1 \mathrm{~mL}$ of sample extract was treated with $20 \mathrm{~mL}$ distilled water, $2.5 \mathrm{~mL}$ Folin-Denis reagent, and $10 \mathrm{~mL}$ of $17 \% \mathrm{Na}_{2} \mathrm{CO}_{3}$ for the development of a bluish-green colour and was allowed to stand for 20 minutes. The absorbance was measured at $760 \mathrm{~nm}$ and amount of tannin was calculated by comparing it with standard curve prepared in the range of $0-10 \mathrm{ppm}$.

2.4.4. Determination of Saponins. Saponin analysis was performed according to the method described by Brunner [31]. $100 \mathrm{~mL}$ Isobutyl alcohol was added to $1 \mathrm{~g}$ of finely powdered sample and stirred for $5 \mathrm{hrs} .20 \mathrm{~mL}$ of $40 \%$ saturated solution of Magnesium carbonate was added to the mixture and filtered. $2 \mathrm{~mL}$ of $5 \% \mathrm{FeCl}_{3}$ solution and $50 \mathrm{~mL}$ volume of distilled water was added to $1 \mathrm{~mL}$ of colourless solution and kept for $30 \mathrm{~min}$ for colour (blood red) development. The absorbance of the samples along with the standard were read at $380 \mathrm{~nm}$ and calculated in $\mathrm{mg} / \mathrm{gm}$. Standard saponin solution was prepared in the reference range of 0-10 ppm.

2.4.5. Determination of Total Phenols. Five grams of the powdered leaves was boiled with $50 \mathrm{~mL}$ of ether for 15 mins and distributed in the ratio $1: 2$ (extract: distilled water). $2 \mathrm{~mL}$ of ammonium hydroxide followed with $5 \mathrm{~mL}$ of pentanol was added to it and incubated at the room temperature for 30 minutes. The absorbance was read at $505 \mathrm{~nm}$ as described by Obodoni and Ochuko [32].

2.5. Procuring of Bacterial Strain. Pure cultures of five test organisms, namely, S. aureus (NCIM 2079), S. epidermidis (NCIM 2493), B. cereus (NCIM 2156), E. aerogenes (NCIM 5139), and K. pneumoniae (NCIM 2957), were procured from National Chemical Laboratory, Pune. Stock cultures were maintained at $4^{\circ} \mathrm{C}$ on agar slants of nutrient media. Active cultures for experiment were prepared by transferring a loop full of microorganism from the stock cultures to $50 \mathrm{~mL}$ of sterile nutrient broth.

2.6. Antibacterial Activity. The extracts mentioned above were tested against five pathogenic bacterial strains, three gram-positive bacteria (B. cereus, S. epidermidis, and $S$. aureus), and two gram-negative bacteria (E. aerogens, $K$. pneumoniae). Antibacterial screening was done using agar well diffusion method [33]. For this $20 \mathrm{~mL}$ of sterile MuellerHinton Agar (Hi-media) was poured in sterile autoclaved petri plates. After solidification, the sterile cotton swab was dipped into the bacterial culture. The entire agar surface of each plate was evenly inoculated by swabbing. The seven uniform wells were prepared with the help of sterile $6 \mathrm{~mm}$ diameter cork-borer. Each well was filled with the various concentrations of both the aqueous and methanol extract (10, $20,25,30$, and $40 \mathrm{mg} / \mathrm{mL}$ ), respectively, whereas, in case of aqueous: ethanol, $(40,80,100$, and $120 \mathrm{mg} / \mathrm{mL})$ concentrations were used and allowed for diffusion for 45 minutes. The plates were then incubated at $37^{\circ} \mathrm{C}$ for $24 \mathrm{hrs}$. Triplicate plates were prepared for each treatment and the average zone of inhibition excluding well was recorded. 9\% DMSO was used as negative control. Turbidity of bacterial culture was maintained up to $1 \times 10^{8} \mathrm{CFU} / \mathrm{mL}$. The antibacterial potential of extracts was compared with standard antibiotic Ampicillin $(10 \mu \mathrm{g} / \mathrm{disc})$ with paper disc (Hi-media) method.

2.7. Gas Chromatography Mass Spectrometry Analysis. The gas chromatography-mass spectrometry (GC-MS) analysis of methanolic extract of leaves of Aegle marmelos (var. Pant Aparna)was performed using a GC-MS (Model; QP 2010 Plus, Shimadzu, Tokyo, Japan) equipped with a VF-5 ms fused silica capillary column of $30 \mathrm{~m}$ length, $0.25 \mathrm{~mm}$ diameter, and $0.25 \mu \mathrm{m}$ film thickness. The column oven temperature was programmed from $80^{\circ} \mathrm{C}$ to $310^{\circ} \mathrm{C}$ for $2^{\circ} \mathrm{C} \mathrm{min}^{-1}$. Ionization of the sample components was performed in electron impact mode $(\mathrm{EI}, 70 \mathrm{eV})$. The temperature of the injector was fixed to $270^{\circ} \mathrm{C}$ and detector to $230^{\circ} \mathrm{C}$. Helium (99.9995\% purity) was the carrier gas fixed with a flow rate of $1.21 \mathrm{~mL} \mathrm{~min}^{-1}$. The mass range from $40-650 \mathrm{~m} / z$ was scanned at a rate of 3.0 scans/s. $2.0 \mu \mathrm{L}$ of the methanolic extract of Aegle marmelos was injected with a Hamilton syringe to the GC-MS manually for total ion chromatographic analysis in split injection technique. Total running time of GC-MS was $56 \mathrm{~min}$. The relative percentage of each extract constituent was expressed as percentage with peak area normalization.

The bioactive compounds of methanol extract were identified by comparing their retention indices and patterns of mass spectra with reference to Wiley Registry of Mass Spectral Data's, New York (Wiley 8) and Fatty Acid Methyl Esters Library version 1.0 (FAME library) sources.

\section{Result and Discussion}

3.1. Phytochemical Profiling. The present study was carried on aqueous and methanolic extracts of Aegle marmelos to investigate the presence of medicinally important phytochemicals in the leaves of different varieties/accessions. Both the extracts revealed the presence of various phytochemicals such as tannins, saponins, flavonoids, alkaloids, terpenoids, carotenoids, cardiac glycosides, and reducing sugars in all the varieties and accessions while phlobatannins and anthocyanins were absent (Table 1). The presence of different phytochemicals and the antimicrobial activity of ethanolic, petroleum ether, chloroform, and methanolic extract of a single unidentified variety of Aegle marmelos have been previously reported $[34,35]$; however, our study is first ever report to the best of our knowledge on qualitative and quantitative comparative analysis of various varieties/accessions available in India. The findings conclude that amongst 18 varieties and accessions, the variety Pant Aparna was found to be the best. The antibacterial activity of this variety using methanol, aqueous, and aqueous: ethanol as the solvent has been investigated. The activity was further confirmed by performing GC-MS which revealed the presence of different phytochemicals.

The quantitative phytochemical estimation specifies that the leaves of all varieties contain a significant amount of alkaloid, flavonoids, phenolic, saponins, and tannin content. 
TABLE 1: Qualitative analysis of phytochemicals in aqueous and methanol extract of different varieties/accessions of Bael (Aegle marmelos) leaves.

\begin{tabular}{|c|c|c|c|c|c|c|c|c|c|c|}
\hline Diff. Bael variety/accessions & ${ }^{\mathrm{a}} \mathrm{TA}$ & ${ }^{\mathrm{b}} \mathrm{PHL}$ & ${ }^{\mathrm{c}} \mathrm{SAP}$ & ${ }^{\mathrm{d}}$ TER & ${ }^{\mathrm{e}} \mathrm{FLA}$ & ${ }^{\mathrm{f}} \mathrm{CAR}$ & ${ }^{\mathrm{g}} \mathrm{ANTH}$ & ${ }^{\mathrm{h}} \mathrm{CAR}$ & ${ }^{\mathrm{i}} \mathrm{RED}$ & ${ }^{\mathrm{j}} \mathrm{ALK}$ \\
\hline NB-17 & + & - & + & + & + & + & - & + & + & + \\
\hline Pant Aparna & + & - & + & + & + & + & - & + & + & + \\
\hline NB-9 & + & - & + & + & + & + & - & + & + & + \\
\hline NB-5 & + & - & + & + & + & + & - & + & + & + \\
\hline AM-4 & + & - & + & + & + & + & - & + & + & + \\
\hline NB-7 & + & - & + & + & + & + & - & + & + & + \\
\hline AM-7 & + & - & + & + & + & + & - & + & + & + \\
\hline AM-3 & + & - & + & + & + & + & - & + & + & + \\
\hline NB-1 & + & - & + & + & + & + & - & + & + & + \\
\hline Kaghzi & + & - & + & + & + & + & - & + & + & + \\
\hline NB-4 & + & - & + & + & + & + & - & + & + & + \\
\hline NB-16 & + & - & + & + & + & + & - & + & + & + \\
\hline P.Sujana & + & - & + & + & + & + & - & + & + & + \\
\hline P.Sujata & + & - & + & + & + & + & - & + & + & + \\
\hline AM-1 & + & - & + & + & + & + & - & + & + & + \\
\hline AM-2 & + & - & + & + & + & + & - & + & + & + \\
\hline AM-6 & + & - & + & + & + & + & - & + & + & + \\
\hline AM-8 & + & - & + & + & + & + & - & + & + & + \\
\hline
\end{tabular}

${ }^{\mathrm{a}}$ TA: tannins; ${ }^{\mathrm{b}} \mathrm{PHL}$ : phlobatannins; ${ }^{\mathrm{c}}$ SAP: saponins; ${ }^{\mathrm{d}}$ TER: terpenoids; ${ }^{\mathrm{e}}$ FLA: flavonoids; ${ }^{\mathrm{f}} \mathrm{CAR}$ : cardiac glycosides; ${ }^{\mathrm{g}}$ ANTH: combined anthraquinones; ${ }^{\mathrm{h}} \mathrm{CAR}$ : carotenoids; ${ }^{\mathrm{i}} \mathrm{RED}$ : reducing sugar; ${ }^{\mathrm{j}} \mathrm{ALK}$ : alkanoids; +: present; -: absent.

TABLE 2: Quantitative estimation of phytochemicals (mg/g).

\begin{tabular}{|c|c|c|c|c|c|}
\hline $\begin{array}{l}\text { Different Bael } \\
\text { variety/accessions }\end{array}$ & Alkaloids & Flavonoids & Phenols & Saponins & Tannins \\
\hline NB-17 & $8.62 \pm 0.10$ & $26.2 \pm 0.065$ & $22.8 \pm 0.004$ & $7.65 \pm 0.14$ & $4.53 \pm 0.15$ \\
\hline Pant Aparna & $16.08 \pm 0.05^{* *}$ & $63.9 \pm 0.061^{* *}$ & $29.4 \pm 0.004^{* *}$ & $11.98 \pm 0.20$ & $8.32 \pm 0.40$ \\
\hline NB-9 & $10.7 \pm 0.15$ & $19.8 \pm 0.058$ & $10.22 \pm 0.032$ & $5.36 \pm 0.15$ & $3.78 \pm 0.35$ \\
\hline NB-5 & $9.56 \pm 0.10$ & $23.2 \pm 0.055$ & $12.6 \pm 0.005$ & $6.57 \pm 0.25$ & $6.43 \pm 0.05$ \\
\hline AM-4 & $11.6 \pm 0.14$ & $23.9 \pm 0.053$ & $11.4 \pm 0.007$ & $4.23 \pm 0.44$ & $4.97 \pm 0.10$ \\
\hline NB-7 & $6.56 \pm 0.25$ & $18.5 \pm 0.051$ & $10.0 \pm 0.005$ & $4.65 \pm 0.10$ & $3.45 \pm 0.25$ \\
\hline AM-7 & $4.28 \pm 0.30$ & $39.1 \pm 0.049$ & $19.6 \pm 0.045$ & $13.40 \pm 0.30$ & $5.76 \pm 0.35$ \\
\hline AM-3 & $14.34 \pm 0.20$ & $28.9 \pm 0.048$ & $17.78 \pm 0.079$ & $12.76 \pm 0.20$ & $7.24 \pm 0.15$ \\
\hline NB-1 & $3.78 \pm 0.15$ & $10.4 \pm 0.047$ & $5.8 \pm 0.085$ & $4.21 \pm 0.45$ & $3.20 \pm 0.25$ \\
\hline Kaghzi & $5.94 \pm 0.15$ & $17.4 \pm 0.046$ & $11.4 \pm 0.004$ & $5.85 \pm 0.35$ & $5.31 \pm 0.18$ \\
\hline NB-4 & $10.57 \pm 0.30$ & $12.4 \pm 0.043$ & $9.6 \pm 0.004$ & $7.50 \pm 0.24$ & $3.60 \pm 0.42$ \\
\hline NB-16 & $5.80 \pm 0.25$ & $10.4 \pm 0.007$ & $7.6 \pm 0.007$ & $3.20 \pm 0.15$ & $4.35 \pm 0.36$ \\
\hline P.Sujana & $7.45 \pm 0.45$ & $16.4 \pm 0.070$ & $15.82 \pm 0.007$ & $6.02 \pm 0.30$ & $6.62 \pm 0.28$ \\
\hline P.Sujata & $11.98 \pm 0.25$ & $23.9 \pm 0.088$ & $13.64 \pm 0.008$ & $8.53 \pm 0.25$ & $6.43 \pm 0.08$ \\
\hline AM-1 & $12.79 \pm 0.20$ & $23.5 \pm 0.225$ & $15.22 \pm 0.082$ & $7.89 \pm 0.55$ & $4.05 \pm 0.24$ \\
\hline AM-2 & $8.43 \pm 0.35$ & $12.4 \pm 0.045$ & $8.6 \pm 0.084$ & $5.9 \pm 0.34$ & $5.32 \pm 0.31$ \\
\hline AM-6 & $15.03 \pm 0.40$ & $26.9 \pm 0.108$ & $20.22 \pm 0.010$ & $10.94 \pm 0.28$ & $10.54 \pm 0.05$ \\
\hline AM-8 & $13.36 \pm 0.25$ & $26.6 \pm 0.078$ & $18.38 \pm 0.078$ & $9.25 \pm 0.55$ & $7.29 \pm 0.18$ \\
\hline
\end{tabular}

refers to significant values $(P<0.01)$.

However the variety called Pant Aparna contains the highest amount of alkaloids, flavonoids, and phenol (Table 2). The alkaloids content was quantitatively estimated and was found in the range of $3.78 \pm 0.15-16.08 \pm 0.05 \mathrm{mg} / \mathrm{gm}$ in different varieties of Bael leaves but the maximum content was observed in Pant Aparna (16.08 $\pm 0.05 \mathrm{mg} / \mathrm{gm})$. Similarly all the varieties exhibited good quantity of flavonoids and phenols starting from $10.4 \pm 0.047 \mathrm{mg} / \mathrm{mL}$ and $5.8 \pm$ $0.085 \mathrm{mg} / \mathrm{mL}$, respectively, in variety NB-1, reaching up to $63.9 \pm 0.061 \mathrm{mg} / \mathrm{mL}$ and $29.4 \pm 0.004$ in Pant Aparna. 
TABLE 3: Zone of Inhibition by aqueous extract.

\begin{tabular}{|c|c|c|c|c|c|c|c|c|}
\hline \multicolumn{9}{|c|}{ Aqueous extract } \\
\hline Conc. $(\mathrm{mg} / \mathrm{mL})$ & 10 & 15 & 20 & 25 & 30 & 40 & Standard & Control \\
\hline Name of bacteria & & & Zone of inh & ibition $(\mathrm{mm}$ & & & Ampicillin (10 mcg/disc) & DMSO \\
\hline K. pneumoniae & $7.33 \pm 0.03$ & $8.33 \pm 0.03$ & $8.5 \pm 0.02$ & $6.5 \pm 0.02$ & $9.83 \pm 0.04$ & $10.6 \pm 0.03$ & $21.3 \pm 0.088$ & 0 \\
\hline B. cereus & $7.33 \pm 0.03$ & $8.33 \pm 0.03$ & 9.00 & 9.00 & $9.00 \pm 0.05$ & $9.33 \pm 0.05^{* *}$ & $10.3 \pm 0.088$ & 0 \\
\hline E. aerogenes & 8.00 & 8.00 & $8.33 \pm 0.03$ & 9.00 & 9.00 & $9.00^{* *}$ & $11.3 \pm 0.088$ & 0 \\
\hline S. aureus & $8.66 \pm 0.03$ & $9.66 \pm 0.03$ & $10.6 \pm 0.03$ & $11.6 \pm 0.03$ & $12.6 \pm 0.03$ & 13.0 & $40.6 \pm 0.120$ & 0 \\
\hline S. epidermidis & $9.66 \pm 0.03$ & 11.0 & 12.0 & 13.0 & $13.6 \pm 0.03$ & $14.3 \pm 0.06^{*}$ & $20.6 \pm 0.145$ & 0 \\
\hline
\end{tabular}

Values are expressed as mean \pm SEM and analyzed by one-way analysis of variance (ANOVA) followed by Dennett's $t$ test; ${ }^{*} P<0.05 ;{ }^{* *} P<0.01$.

TABLE 4: Zone of inhibition by methanol extract.

\begin{tabular}{lccccccc}
\hline \multicolumn{7}{c}{ Methanol extract } \\
\hline Conc. $(\mathrm{mg} / \mathrm{mL})$ & 10 & 15 & 20 & 25 & 30 & 40 & Standard \\
\hline Name of bacteria & & \multicolumn{7}{c}{ Zone of inhibition $(\mathrm{mm})$} & Control \\
\hline K. pneumoniae & $9.3 \pm 0.03$ & $9.6 \pm 0.03$ & $10.6 \pm 0.03$ & $11.3 \pm 0.03$ & $11.0 \pm 0.05$ & $11.0 \pm 0.05^{*}$ & $21.3 \pm 0.088$ \\
B. cereus & $8.6 \pm 0.03$ & 10.0 & $10.6 \pm 0.03$ & $11.3 \pm 0.03$ & $10.6 \pm 0.03$ & $12.0 \pm 0.05^{* *}$ & $10.3 \pm 0.088$ \\
E. aerogenes & - & - & - & - & - & - & $11.3 \pm 0.088$ \\
S. aureus & 10.0 & 11.0 & 11.0 & $12.3 \pm 0.03$ & 12.0 & 13.0 & $40.6 \pm 0.120$ \\
S. epidermidis & $8.0 \pm 0.05$ & $9.3 \pm 0.06$ & 10.0 & $10.3 \pm 0.03$ & 11.0 & $12.0^{*}$ & 0 \\
\hline
\end{tabular}

Values are expressed as mean \pm SEM and analyzed by one-way analysis of variance (ANOVA) followed by Dennett's $t$ test; ${ }^{*} P<0.05 ;{ }^{* *} P<0.01$.

Earlier report on quantitative yield also revealed that Aegle marmelos contained highest quantity of alkaloids, flavonoids, and tannins as compared to other medicinal plants [36]. The highest content of saponins was found in variety AM-7 (13.40 \pm 0.30$)$ followed by Pant Aparna and AM-6. Among all the varieties analysed, Pant Aparna was found to be the most promising one, which prompted us to project Pant Aparna for further studies.

3.2. Antibacterial Study. The pharmacological action of the plant cannot be ascertained by the result of phytochemical studies only. Thus the antibacterial activity against pathogenic bacteria was also evaluated. The present investigation shows the efficacy of all the extracts against the selected pathogenic bacteria (Tables 3, 4, and 5).

The aqueous extract showed highest antibacterial activity against $S$. epidermidis $(14.3 \mathrm{~mm})$ followed by $S$. aureus $(13 \mathrm{~mm})$ and $K$. pneumonia $(10.6 \mathrm{~mm})$. The maximum zone of inhibition was observed at the concentration of $40 \mathrm{mg} / \mathrm{mL}$. Varying degree of antibacterial activity by leaf extracts of Aegle marmelos against various tested bacterial species has been reported [37]. The presence of the compounds Cuminaldehyde and Eugenol may be responsible for the antibacterial activity of leaf extracts against various bacterial strains [38]. The aqueous, acetone, and petroleum ether extracts of $A$. marmelos were found to be effective against $B$. coagulans, B. subtilis, B. thuringiensis, P. aeruginosa, and $S$. aureus as reported earlier [39]. The dried fruit extract of Aegle marmelos showed potential antibacterial activity against $P$. aeruginosa, S. flexneri, E. coli, B. subtilis, S. epidermidis, and S. aureus [40].

On the other hand, the methanol extract exhibited a much better antibacterial activity as compared to aqueous extract against $K$. pneumoniae, B. cereus, and S. aureus. The methanol extract was most potent against $S$. aureus, showing the maximum zone of inhibition at the concentration of $40 \mathrm{mg} / \mathrm{mL}$. The highest sensitivity of $S$. aureus may be due to its cell wall structure and outer membrane [41]. No activity was seen against E. aerogenes. A few reports have also mentioned significant in vitro antimicrobial activity by the methanol extracts of Aegle marmelos leaves and flowers $[35,42]$. The MIC value of both aqueous and methanol extract was significant at $10 \mathrm{mg} / \mathrm{mL}$; however, for aqueous: ethanol it was $40 \mathrm{mg} / \mathrm{mL}$ which is analogous to the MIC values reported using crude extracts of other medicinal plants. The antimicrobial activity of papaya seed extract with MIC value of $11.8 \mathrm{mg} / \mathrm{mL}$ was found to be effective against S. typhi by Yismaw et al. [43]. In Zizyphus sp. MIC values of $25 \mathrm{mg} / \mathrm{mL}$ [44] have been reported against $S$. aureus. Similarly, in case of F. religiosa, the final MIC values were 2-4-fold higher than initial MIC which ranged from 4.7 to $18.8 \mathrm{mg} / \mathrm{mL}$ and from 2.4 to $18.8 \mathrm{mg} / \mathrm{mL}$ for resistant and for sensitive isolates, respectively. MIC values $(25 \mathrm{mg} / \mathrm{mL})$ were reported by Valsaraj et al. [44] while higher concentration of $150 \mathrm{mg} / \mathrm{mL}$ was reported by Ahmad and Beg [45] against S. aureus. In yet another study, the antibacterial activity of whole plant of Borreria hispida (Linn) was evaluated against various organisms, where the MIC of methanolic extract of Borreria hispida was found to range from $250 \mu \mathrm{g} / \mathrm{mL}$ to $50 \mathrm{mg} / \mathrm{mL}$. Moreover higher MIC values ranging from 0.125 to $32 \mathrm{mg} / \mathrm{mL}$ were also reported against at least one of the test microorganisms from nine ethnobotanically Indian medicinal plants [46].

The high antibacterial activity in the methanolic extract may be due to the presence of tannins, flavonoids, and terpenoids. These medicinally bioactive components exert 
TABLE 5: Zone of inhibition by aqueous: ethanol extract.

\begin{tabular}{lcccc}
\hline & \multicolumn{4}{c}{ Aqueous: ethanol } \\
\hline Conc. $(\mathrm{mg} / \mathrm{mL})$ & 40 & 80 & 120 & 160 \\
\hline Name of bacteria & \multicolumn{4}{c}{ Zone of inhibition $(\mathrm{mm})$} \\
\hline K. pneumonia & $9.0 \pm 0.05$ & $11.0 \pm 0.05$ & $12.3 \pm 0.03$ & $14.6 \pm 0.06^{*}$ \\
B. cereus & 9.0 & 10.0 & 11.0 & $11.3 \pm 0.03$ \\
E. aerogenes & 10.0 & 15.0 & 16.0 & $18.3 \pm 0.03^{* *}$ \\
S. aureus & $10.3 \pm 0.03$ & $11.6 \pm 0.03$ & 12.0 & 13.0 \\
S. epidermidis & $10.3 \pm 0.03$ & $12.3 \pm 0.03$ & $13.3 \pm 0.06$ & $14.6 \pm 0.03^{*}$ \\
\hline
\end{tabular}

Values are expressed as mean \pm SEM and analyzed by one-way analysis of variance (ANOVA) followed by Dennett's $t$ test; ${ }^{*} P<0.05$; ${ }^{* *} P<0.01$. The standard antibiotic and control are the same as that of aqueous and methanolic extract.

antimicrobial action through different mechanism. Tannins cause inhibition in the cell wall synthesis by forming irreversible complexes with prolene rich protein [47]. The saponins have the ability to cause leakage of proteins and certain enzymes from the cell [48]. Terpenoids are responsible for dissolution of the cell wall of microorganism by weakening the membranous tissue [49]. Flavonoids which have been found to be effective antimicrobial substances against a wide array of microorganisms in vitro are known to be synthesized in response to microbial infection by plants. They have the ability to complex with extracellular and soluble proteins and to complex with bacterial cell walls [50]. Furthermore, steroids are known for their antibacterial activity specifically associated with membrane lipids and cause leakage from liposomes [51].

In the case of aqueous: ethanol, the maximum antibacterial activity was seen against $E$. aerogenes followed by $S$. epidermidis and K. pneumonia (Table 5). At the highest concentration of $160 \mathrm{mg} / \mathrm{mL}$ it showed $18.3 \mathrm{~mm}$ zone of inhibition. The antibiotic susceptibility showed that among all the bacterial strains $S$. aureus was found to be more susceptible to ampicillin followed by $K$. pneumonia.

3.3. GC-MS Analysis. In all, thirty-three compounds were identified from the GC-MS analysis of methanolic extract of Bael leaves exhibiting various phytochemical activities and were predominantly responsible for the antimicrobial activity found in the extract against the pathogenic bacteria. The retention time and percentage peak of various bioactive compounds are presented in Table 6. The major phytoconstituents present in the leaf extract were 1-Dodecanol (4.83), 4H-Pyran-4-one, 2,3-dihydro-3,5dihydroxy-6-methyl-(1.11), 2,3Dioxabicyclo[2.2.2] oct-5-ene, 1-Methyl-4-(1-Methylethyl)-(Limonene dioxide 1) occupying two peak areas, that is, (0.53) and (0.40), Bicyclo[3.1.1] heptane-2,3-diol, 2,6,6-trimethyl (2,3-Pinanediol)(0.97), 2Cyclohexen-1-one, 4-hydroxy-3-methyl-6-(1-methylethyl)(0.63, 0.41, 0.17), Phenol, 2,6-bis(1,1-dimethylethyl)-4methyl-(BHT) (0.87), Tetradecanoic acid (Myristic acid) (2.00), 2(4H)-Benzofuranone 5,6,7,7A-Tetrahydro-6hydroxy-4,4,7a-trimethyl,1,3-cyclohexadiene,2-methyl-

5-(1methylethyl)-(1-Phellandrene), 2-Propenoic acid, 3-(4-hydroxy-3-methoxyphenyl)-, methyl ester (Cinnamic acid, 4-hydroxy-3-methoxy-, methyl ester), 3,7,11,15Tetramethyl-2-hexadecen-1-ol, commonly known as phytol; a diterpene has significant antimicrobial properties against many bacterial strains [52]. 9,12,15-Octadecatrienoic acid, methyl ester (Linolenic acid, methyl ester) showing antibacterial and anticandidal activity, 2-Hexadecen-1-ol, 3,7,11,15-Tetramethyl (Phytol isomer) (6.37), Octadecanoic acid (Stearic acid) (4.07), Benzene, 1,2-dimethoxy-4-[[(4 methylphenyl) sulfonyl]methyl (10.76), fatty alcohols such as Ergost-5-en-3-ol, (3.beta.) (campesterol), Stigmasta5, 22-dien-3-ol, Stigmast-5-en-3-ol, (3.beta.)- may be synergistically responsible for the antimicrobial activity.

The different phyto compounds responsible for bioactivity have been identified and characterized in different medicinal plants. 4H-Pyran-4-one, 2,3-dihydro-3, 5-dihydroxy-6methyl-, a potent anti-inflammatory and antioxidant compound, possessed antibacterial activity in Barleria prionitis (Linn.) rhizome. A long-chain fatty alcohol, 1-Dodecanol, was reported with highest antibacterial activity against Staphylococcus aureus [53]. Phenol, 2,6-bis(1,1-dimethylethyl)-4methyl commonly known as Butylated hydroxytoluene (BHT), an antioxidant, has also demonstrated marked antimicrobial activity inhibiting or decreasing the growth of gram-positive bacteria at a higher degree than the gram-negative bacteria belonging to the family Enterobacteriaceae [54]. Derivatives of cinnamic acid such as esters, amides, acids, and hydrazides have been reported to have antibacterial, antifungal, and antiviral properties [55]. 2(4H)-Benzofuranone, 5,6,7,7a-tetrahydro-4,4,7atrimethyl, a bioactive compound possessing the properties such as analgesic, antidiabetic, antibacterial, and antifungal, was identified from the methanolic fractions of the Azadirachta indica [56]. The extract contained (0.23\%) of 1,3-Cyclohexadiene, 2-methyl-5-(1-methylethyl), commonly known as 1-phellandrene. Stigmasterol has been reported earlier as a strong antioxidant having antibacterial activity against multidrug resistant mycobacteria $[57,58]$.

Several bioactive compounds, namely, Marmin [59] and Marmelosin coumarin derivatives [60] and Aegeline, an alkaloid, have been previously reported from Aegle marmelos [61]. However the flavonoids and phenolics present in significant amount in this plant are still unexplored. The preferential quantity of these compounds in the methanolic extract of Pant Aparna as revealed by the present study directed to focus 
TABLE 6: Activity of the phytocomponents identified from methanolic leaf extract of Aegle marmelos.

\begin{tabular}{|c|c|c|c|c|c|c|c|}
\hline S. no. & R.T & Compound name & $\begin{array}{l}\text { Molecular } \\
\text { formula }\end{array}$ & MW & $\begin{array}{c}\text { Peak } \\
\text { area } \%\end{array}$ & $\begin{array}{c}\text { Compound } \\
\text { nature }\end{array}$ & ${ }^{* *}$ Activity \\
\hline 1 & 7.178 & $\begin{array}{l}\text { 4H-Pyran-4-one, } \\
\text { 2,3-dihydro-3,5-dihydroxy-6-methyl- }\end{array}$ & $\mathrm{C}_{6} \mathrm{H}_{8} \mathrm{O}_{4}$ & 144 & 1.11 & Flavonoid fraction & $\begin{array}{l}\text { Antimicrobial, } \\
\text { anti-inflammatory, } \\
\text { antiproliferative }\end{array}$ \\
\hline 2 & 6.555 & 1-Butanol, 3-methyl-, acetate & $\mathrm{C}_{7} \mathrm{H}_{14} \mathrm{O}_{2}$ & 130 & 5.32 & $\begin{array}{l}\text { Alcoholic } \\
\text { compound }\end{array}$ & Antimicrobial \\
\hline 3 & 12.09 & $\begin{array}{l}\text { 2,3 Dioxabicyclo[2.2.2] oct-5-ene, } \\
\text { 1-methyl-4-(1-methylethyl)-(Limonene } \\
\text { dioxide 1) }\end{array}$ & $\mathrm{C}_{10} \mathrm{H}_{16} \mathrm{O}_{2}$ & 168 & 0.53 & Terpene & $\begin{array}{l}\text { antimicrobial } \\
\text { activity }\end{array}$ \\
\hline 4 & 13.385 & $\begin{array}{l}\text { Bicyclo[3.1.1]heptane-2,3-diol, } \\
\text { 2,6,6-trimethyl } \\
\text { (2,3-Pinanediol) }\end{array}$ & $\mathrm{C}_{10} \mathrm{H}_{18} \mathrm{O}_{2}$ & 170 & 0.97 & Terpene & $\begin{array}{l}\text { antimicrobial } \\
\text { activity }\end{array}$ \\
\hline 4 & 13.762 & $\begin{array}{l}\text { 2-Cyclohexen-1-one, } \\
\text { 4-hydroxy-3-methyl-6-(1-methylethyl)- }\end{array}$ & $\mathrm{C}_{10} \mathrm{H}_{16} \mathrm{O}_{2}$ & 168 & 0.63 & & antibacterial \\
\hline 5 & 15.203 & 1-Dodecanol & $\mathrm{C}_{12} \mathrm{H}_{26} \mathrm{O}$ & 186 & 4.83 & $\begin{array}{l}\text { long-chain fatty } \\
\text { alcohol }\end{array}$ & antibacterial \\
\hline 6 & 16.143 & $\begin{array}{l}\text { Phenol, } \\
\text { 2,6-bis(1,1-dimethylethyl)-4-methyl } \\
\text { (BHT) }\end{array}$ & $\mathrm{C}_{15} \mathrm{H}_{24} \mathrm{O}$ & 220 & 0.87 & & $\begin{array}{l}\text { Antimicrobial, antioxidant } \\
\text { activity }\end{array}$ \\
\hline 7 & 16.457 & Benzoic acid, 4-ethoxy-, ethyl ester & $\mathrm{C}_{11} \mathrm{H}_{14} \mathrm{O}_{3}$ & 194 & 0.33 & $\begin{array}{l}\text { Aromatic } \\
\text { acid ester }\end{array}$ & Antimicrobial Preservative \\
\hline 8 & 18.101 & $\begin{array}{l}\text { 2-Propanol, 1,1'-[(1-methyl-1,2- } \\
\text { ethanediyl)bis(oxy)]bis-(Tripropylene } \\
\text { glycol) }\end{array}$ & $\mathrm{C}_{9} \mathrm{H}_{20} \mathrm{O}_{4}$ & 192 & 0.87 & & $\begin{array}{l}\text { Antimicrobial } \\
\text { activity }\end{array}$ \\
\hline 9 & 20.189 & 1-Tetradecanol, acrylate & $\mathrm{C}_{17} \mathrm{H}_{32} \mathrm{O}_{2}$ & 268 & 1.46 & Fatty acid esters & $\begin{array}{l}\text { Anti-inflammatory, } \\
\text { antimicrobial }\end{array}$ \\
\hline 10 & 20.523 & $\begin{array}{l}\text { 1,3,4,5-Tetrahydroxy- } \\
\text { cyclohexanecarboxylic acid } \\
\text { (Quinic acid) }\end{array}$ & $\mathrm{C}_{7} \mathrm{H}_{12} \mathrm{O}_{6}$ & 192 & 0.39 & Aromatic acid & $\begin{array}{l}\text { antimicrobial } \\
\text { activity, anti-inflammatory }\end{array}$ \\
\hline 11 & 21.839 & $\begin{array}{l}\text { Tetradecanoic acid } \\
\text { (Myristic acid) }\end{array}$ & $\mathrm{C}_{14} \mathrm{H}_{28} \mathrm{O}_{2}$ & 228 & 2.00 & Fatty acid & $\begin{array}{l}\text { Antifungal, Antioxidant, } \\
\text { cancer preventive, } \\
\text { nematicide, } \\
\text { hypercholesterolemic, } \\
\text { Lubricant }\end{array}$ \\
\hline 12 & 22.070 & $\begin{array}{l}\text { 2(4H)-Benzofuranone } 5,6,7,7 \mathrm{a} \text { - } \\
\text { tetrahydro-6-hydroxy-4,4,7a-trimethyl }\end{array}$ & $\mathrm{C}_{11} \mathrm{H}_{16} \mathrm{O}_{3}$ & 196 & 0.26 & Triterpene & antimicrobial \\
\hline 13 & 22.262 & $\begin{array}{l}\text { 1-Heptadecanol } \\
\text { (1-Eicosanol) }\end{array}$ & $\mathrm{C}_{17} \mathrm{H}_{36} \mathrm{O}$ & 256 & 0.33 & Aliphatic alcohol & $\begin{array}{l}\text { Antimalarial, antifungal, } \\
\text { Antioxidant }\end{array}$ \\
\hline 14 & 22.409 & $\begin{array}{l}\text { 1,3-Cyclohexadiene, 2-methyl-5-(1- } \\
\text { methylethyl)-(1-Phellandrene) }\end{array}$ & $\mathrm{C}_{10} \mathrm{H}_{16}$ & 136 & 0.23 & Monoterpene & Antibacterial \\
\hline 15 & 22.736 & $\begin{array}{l}\text { 1,6-Octadiene, 7-methyl-3-methylene } \\
\text { (beta.-myrcene) }\end{array}$ & $\mathrm{C}_{10} \mathrm{H}_{16}$ & 136 & 0.13 & Monoterpene & Antibacterial \\
\hline 16 & 23.404 & $\begin{array}{l}\text { 2-Propenoic acid, } \\
\text { 3-(4-hydroxy-3-methoxyphenyl)-, methyl } \\
\text { ester } \\
\text { (Cinnamic acid, 4-hydroxy-3-methoxy-, } \\
\text { methyl ester ) }\end{array}$ & $\mathrm{C}_{11} \mathrm{H}_{12} \mathrm{O}_{4}$ & 208 & 0.66 & $\begin{array}{l}\text { Aromatic methyl } \\
\text { esters }\end{array}$ & $\begin{array}{l}\text { Antimicrobial, } \\
\text { antioxidant, antiviral }\end{array}$ \\
\hline 17 & 23.819 & Pentadecanoic acid & $\mathrm{C}_{15} \mathrm{H}_{30} \mathrm{O}_{2}$ & 242 & 0.08 & Fatty acid & Antibacterial \\
\hline 18 & 24.897 & $\begin{array}{l}\text { 3,7,11,15-Tetramethyl-2-hexadecen-1-ol } \\
\text { (Phytol) }\end{array}$ & $\mathrm{C}_{20} \mathrm{H}_{40} \mathrm{O}$ & 296 & 0.32 & Diterpene & $\begin{array}{l}\text { Antimicrobial, anticancer, } \\
\text { anti-inflammatory, } \\
\text { anti-diuretic, }\end{array}$ \\
\hline
\end{tabular}


TABle 6: Continued.

\begin{tabular}{|c|c|c|c|c|c|c|c|}
\hline S. no. & R.T & Compound name & $\begin{array}{l}\text { Molecular } \\
\text { formula }\end{array}$ & MW & $\begin{array}{c}\text { Peak } \\
\text { area \% }\end{array}$ & $\begin{array}{l}\text { Compound } \\
\text { nature }\end{array}$ & ${ }^{* *}$ Activity \\
\hline 19 & 24.986 & $\begin{array}{l}\text { hexadecanoic acid, methyl ester } \\
\text { (Palmitic acid methyl ester) }\end{array}$ & $\mathrm{C}_{17} \mathrm{H}_{34} \mathrm{O}_{2}$ & 270 & 0.72 & $\begin{array}{l}\text { Fatty acid methyl } \\
\text { ester }\end{array}$ & $\begin{array}{l}\text { Antioxidant, } \\
\text { hypocholesterolemic } \\
\text { nematicide, pesticide, } \\
\text { antiandrogenic flavor, } \\
\text { hemolytic, 5-Alpha reductase } \\
\text { inhibitor }\end{array}$ \\
\hline 20 & 24.951 & Pentadecanoic acid & $\mathrm{C}_{15} \mathrm{H}_{30} \mathrm{O}_{2}$ & 242 & 7.99 & Saturated fatty acid & Antimicrobial \\
\hline 21 & 27.266 & 9-Octadecenoic acid & $\mathrm{C}_{18} \mathrm{H}_{34} \mathrm{O}_{2}$ & 282 & 0.31 & $\begin{array}{l}\text { Unsaturated fatty } \\
\text { acid }\end{array}$ & antibacterial \\
\hline 22 & 27.664 & Heptadecanoic acid & $\mathrm{C}_{17} \mathrm{H}_{34} \mathrm{O}_{2}$ & 270 & 0.39 & Saturated fatty acid & Antimicrobial \\
\hline 23 & 28.298 & $\begin{array}{l}\text { 9,12,15-Octadecatrienoic acid, methyl } \\
\text { ester } \\
\text { (Linolenic acid, methyl ester) }\end{array}$ & $\mathrm{C}_{19} \mathrm{H}_{32} \mathrm{O}_{2}$ & 292 & 1.07 & $\begin{array}{l}\text { Fatty acid methyl } \\
\text { ester }\end{array}$ & $\begin{array}{l}\text { Antibacterial and anticandidal } \\
\text { Antiinflammatory, } \\
\text { hypocholesterolemic, cancer } \\
\text { preventive, } \\
\text { hepatoprotective, nematicide, } \\
\text { insectifuge antihistaminic, } \\
\text { antiarthritic, anticoronary, } \\
\text { antieczemic antiacne, 5-Alpha } \\
\text { reductase inhibitor } \\
\text { Antiandrogenic }\end{array}$ \\
\hline 24 & 28.554 & $\begin{array}{l}\text { 2-Hexadecen-1-ol, 3,7,11,15-tetramethyl } \\
\text { (Phytol isomer) }\end{array}$ & $\mathrm{C}_{20} \mathrm{H}_{40} \mathrm{O}$ & 296 & 6.37 & Diterpene & $\begin{array}{l}\text { Antimicrobial } \\
\text { Anti-inflammatory } \\
\text { Anticancer Diuretic }\end{array}$ \\
\hline 25 & 29.227 & Cis-9-Hexadecenal & $\mathrm{C}_{16} \mathrm{H}_{30} \mathrm{O}$ & 238 & 11.40 & Aldehyde & Antimicrobial \\
\hline 26 & 29.573 & $\begin{array}{l}\text { Octadecanoic acid } \\
\text { (Stearic acid) }\end{array}$ & $\mathrm{C}_{18} \mathrm{H}_{36} \mathrm{O}_{2}$ & 284 & 4.06 & Fatty acid & Antimicrobial \\
\hline 27 & 41.240 & $\begin{array}{l}\text { Benzene, 1,2-dimethoxy-4-[[(4 } \\
\text { methylphenyl)sulfonyl]methyl }\end{array}$ & $\mathrm{C}_{16} \mathrm{H}_{18} \mathrm{O}_{4} \mathrm{~S}$ & 306 & 10.76 & $\begin{array}{l}\text { Aromatic sulfur } \\
\text { compound }\end{array}$ & Antimicrobial \\
\hline 28 & 44.155 & Cholest-5-en-3-ol (3.beta.)- & $\mathrm{C}_{27} \mathrm{H}_{46} \mathrm{O}$ & 386 & 0.24 & Steroidal & Antibacterial \\
\hline 29 & 45.238 & Ergost-5-en-3-ol, (3.beta.)- & $\mathrm{C}_{27} \mathrm{H}_{46} \mathrm{O}$ & 386 & 0.50 & Steroidal & $\begin{array}{l}\text { Antimicrobial, } \\
\text { anti-inflammatory } \\
\text { effects }\end{array}$ \\
\hline 30 & 45.509 & Stigmasta-5,22-dien-3-ol & $\mathrm{C}_{29} \mathrm{H}_{48} \mathrm{O}$ & 412 & 0.63 & Steroidal & $\begin{array}{l}\text { Antioxidant, } \\
\text { antibacterial activity, } \\
\text { antiinflammatory, antiarthritic } \\
\text { antiasthma, diuretic }\end{array}$ \\
\hline 31 & 46.038 & Stigmast-5-en-3-ol, (3.beta.)- & $\mathrm{C}_{29} \mathrm{H}_{50} \mathrm{O}$ & 414 & 3.08 & Steroidal & $\begin{array}{l}\text { Antimicrobial antioxidant } \\
\text { antiinflammatory antiarthritic } \\
\text { antiasthma diuretic }\end{array}$ \\
\hline 32 & 47.033 & Vitamin E & $\mathrm{C}_{29} \mathrm{H}_{50} \mathrm{O}_{2}$ & 430 & 0.58 & & $\begin{array}{l}\text { Antioxidant and } \\
\text { Antimicrobial activity } \\
\text { Analgesic, } \\
\text { Antidiabatic } \\
\text { Antiinflammatory, } \\
\text { Antidermatitic, } \\
\text { Antileukemic, } \\
\text { Antitumor, } \\
\text { Anticancer, } \\
\text { Hepatoprotective, } \\
\text { Antispasmodic }\end{array}$ \\
\hline
\end{tabular}


TABLE 6: Continued.

\begin{tabular}{|c|c|c|c|c|c|c|c|}
\hline S. no. & R.T & Compound name & $\begin{array}{c}\text { Molecular } \\
\text { formula }\end{array}$ & MW & $\begin{array}{c}\text { Peak } \\
\text { area \% }\end{array}$ & $\begin{array}{c}\text { Compound } \\
\text { nature }\end{array}$ & ${ }^{* *}$ Activity \\
\hline 33 & 44.454 & alpha.-Tocopherol & $\mathrm{C}_{29} \mathrm{H}_{50} \mathrm{O}_{2}$ & 430 & 0.26 & & $\begin{array}{l}\text { Anti-inflammatory, } \\
\text { antioxidant, antimicrobial, } \\
\text { radical scavenging, } \\
\text { antispasmodic }\end{array}$ \\
\hline
\end{tabular}

** Source: Dr. Duke’s: Phytochemical and Ethnobotanical Databases.

towards the purification and characterization of potential compound from this variety.

\section{Conclusion}

Medicines derived from plants have made immense contribution towards the betterment of human health and act as a source of inspiration for novel drug compounds. From the above research it can be concluded that this plant has immense potential to be used in the area of pharmacology and as a prospective source of valuable drugs. Due to the presence of various compounds that are essential for good health, it can also be used to improve the health status of society. The extracts showed a significantly high antibacterial activity against the microorganisms. The data clearly depicts the presence of compounds used for treating various bacterial diseases, indicating its use in the traditional system of medicine since ancient times. Further, the broad spectrum activity of aqueous, methanol, and aqueous: ethanol extracts proves to be encouraging in the development of novel antimicrobial formulation in the near future.

A spectrum of compounds showing strong antibacterial, antioxidant, and anti-inflammatory activities was revealed by the GC-MS analysis of the methanolic extract of Aegle marmelos.

Antimicrobials derived from plants possess vast curative properties since they have fewer side effects as compared to synthetic antimicrobials drugs. Aegle marmelos is of utmost importance for ethnobotanical purposes, and it has been placed in the priority list of thirty-two medicinal plants by The National Medicinal Plants Board of Govt. of India [62]. The present study contributes to the current knowledge of presence of various phytochemical active compounds in 18 varieties/accessions of Aegle marmelos possessing significant broad spectrum antibacterial efficacy. Further fractionation and purification will elucidate the potential compound, which is a pressing need because of the upcoming resistance of the currently available antibiotics.

\section{Conflict of Interests}

The authors declare that there is no conflict of interests regarding the publication of this paper.

\section{Acknowledgments}

The authors would like to gratefully acknowledge UGC, New Delhi, for its financial support in the form of Maulana Azad
National Fellowship and Hon'ble Vice Chancellor of our Integral University.

\section{References}

[1] N. Shariff, M. S. Sudarshana, S. Umesha, and P. Hariprasad, "Antimicrobial activity of Rauvolfia tetraphylla and Physalis minima leaf and callus extracts," African Journal of Biotechnology, vol. 5, no. 10, pp. 946-950, 2006.

[2] G. Vines, "Herbal harvests with a future: towards sustainable sources for medicinal plants," 2004, Plant life International, http://www.plantlife.org.uk/.

[3] B. L. Saet, H. C. Kwang, N. K. Su et al., "The antimicrobial activity of essential oil from Dracocephalum foetidum against pathogenic microorganisms," Journal of Microbiology, vol. 45, no. 1, pp. 53-57, 2007.

[4] P. H. Davis, Flora of Turkey and East Eagean Island, vol. 7, Edinburg University Press, Edinburg, Tex, USA, 1982.

[5] M. Lis-Balchin and S. G. Deans, "Bioactivity of selected plant essential oils against Listeria monocytogenes," Journal of Applied Microbiology, vol. 82, no. 6, pp. 759-762, 1997.

[6] D. A. Ates and O. T. Erdogrul, "Antimicrobial activities of various medicinal and commercial plant extract," Turkish Journal of Biology, vol. 27, pp. 157-162, 2003.

[7] H. R. El-Seedi, T. Ohara, N. Sata, and S. Nishiyama, "Antimicrobial diterpenoids from Eupatorium glutinosum (Asteraceae)," Journal of Ethnopharmacology, vol. 81, no. 2, pp. 293-296, 2002.

[8] R. Rojas, B. Bustamante, J. Bauer, I. Fernández, J. Albán, and O. Lock, "Antimicrobial activity of selected Peruvian medicinal plants," Journal of Ethnopharmacology, vol. 88, no. 2-3, pp. 199204, 2003.

[9] V. Duraipandiyan, M. Ayyanar, and S. Ignacimuthu, "Antimicrobial activity of some ethnomedicinal plants used by Paliyar tribe from Tamil Nadu, India," BMC Complementary and Alternative Medicine, vol. 6, article 35, 2006.

[10] Chemexcil, Selected Medicinal Plants of India, Basic Chemicals, Pharmaceutical and Cosmetic Export Promotion Council, Bombay, India, 1992.

[11] L. Badam, S. S. Bedekar, K. B. Sonawane, and S. P. Joshi, "In vitro antiviral activity of bael (Aegle marmelos Corr.) upon human coxsackieviruses B1-B6," Journal of Communicable Diseases, vol. 34, no. 2, pp. 88-99, 2002.

[12] Y. L. Chew, J. K. Goh, and Y. Y. Lim, "Assessment of in vitro antioxidant capacity and polyphenolic composition of selected medicinal herbs from Leguminosae family in Peninsular Malaysia," Food Chemistry, vol. 116, no. 1, pp. 13-18, 2009.

[13] A. K. Gupta and N. Tandon, Reviews on Indian Medicinal Plants, vol. 1, Indian Council of Medicinal Research, New Delhi, India, 2004. 
[14] N. Kamalakkannan and P. Stanely Mainzen Prince, "Antihyperlipidaemic effect of Aegle marmelos fruit extract in streptozotocin-induced diabetes in rats," Journal of the Science of Food and Agriculture, vol. 85, no. 4, pp. 569-573, 2005.

[15] V. Arul, S. Miyazaki, and R. Dhananjayan, "Studies on the antiinflammatory, antipyretic and analgesic properties of the leaves of Aegle marmelos Corr." Journal of Ethnopharmacology, vol. 96, no. 1-2, pp. 159-163, 2005.

[16] G. C. Jagetia, P. Venkatesh, and M. S. Baliga, “Aegle marmelos (L.) Correa inhibits the proliferation of transplanted Ehrlich ascites carcinoma in mice," Biological and Pharmaceutical Bulletin, vol. 28, no. 1, pp. 58-64, 2005.

[17] N. Kamalakkannan and P. S. M. Prince, "Hypoglycaemic effect of water extracts of Aegle marmelos fruits in streptozotocin diabetic rats," Journal of Ethnopharmacology, vol. 87, no. 2-3, pp. 207-210, 2003.

[18] M. Rajadurai, M. Padmanabhan, and P. S. M. Prince, "Effect of Aegle marmelos leaf extract and alpha-tocopherol on lipid peroxidation and antioxidants in isoproterenol-induced myocardial infarction in rats," Cardiology, vol. 1, pp. 40-45, 2005.

[19] M. C. Sabu and R. Kuttan, "Antidiabetic activity of Aegle marmelos and its relationship with its antioxidant properties," Indian Journal of Physiology and Pharmacology, vol. 48, no. 1, pp. 81-88, 2004.

[20] K. Saradha Jyothi and B. Subba Rao, "Antibacterial activity of extracts from Aegle marmelos against standard pathogenic bacterial strains," International Journal of PharmTech Research, vol. 2, no. 3, pp. 1824-1826, 2010.

[21] T. K. Sur, S. Pandit, and T. Pramanik, "Antispermatogenic activity of leaves of Aegle marmelos corr. in albino rats: a preliminary report," Biomedicine, vol. 19, no. 3, pp. 199-202, 1999.

[22] G. C. Yen, P. D. Duh, and C. L. Tsai, "Relationship between antioxidant activity and maturity of peanut hulls," Journal of Agricultural and Food Chemistry, vol. 41, no. 5, pp. 67-70, 1993.

[23] C. Kingston, S. Jeeva, G. M. Jeeva, S. Kiruba, B. P. Mishra, and D. Kannan, "Indigenous knowledge of using medicinal plants in treating skin diseases in Kanyakumari District, Southern India," Indian Journal of Traditional Knowledge, vol. 8, no. 2, pp. 196200, 2009.

[24] M. M. Cowan, "Plant products as antimicrobial agents," Clinical Microbiology Reviews, vol. 12, no. 4, pp. 564-582, 1999.

[25] J. B. Harborne, Phytochemical Methods, Chapman \& Hall, New York, NY, USA, 11th edition, 1984.

[26] A. O. Adetuyi and A. V. Popoola, "Extraction and dyes ability potential studies of the colourant in zanthoxylum zanthoxyloides plant on cotton fabric," Journal of Science Engineering Technology, vol. 8, no. 2, pp. 3291-3299, 2001.

[27] G. E. Trease and W. C. Evans, Pharmacognosy, Brailliar Tiridal Can Macmillian Publishers, 11th edition, 1989.

[28] A. Sofowora, Medicinal Plants and Traditional Medicine in West Africa, John Wiley and Sons, New York, NY, USA, 1982.

[29] J. B. Harborne, Phytochemical Methods: A Guide to Modern Techniques of Plant Analysis, Chapman \& Hall Ltd., London, UK, 1973.

[30] T. Swain, "Tannins and lignins," in Herbivores: Their Interactions with Plant Metabolites, G. A. Rosenthal and D. H. Janzen, Eds., Academic Press, New York, NY, USA, 1979.

[31] J. H. Brunner, "Direct spectrophotometric determination of saponins," Analytical Chemistry, vol. 34, pp. 1314-1326, 1984.
[32] B. O. Obodoni and P. O. Ochuko, "Phytochemical studies and comparative efficacy of the crude extracts of some Homostatic plants in Edo and Delta States of Nigeria," Global Journal of Pure Applied Science, vol. 8, no. 3, pp. 203-208, 2001.

[33] P. O. Olutiola, O. Famurewa, and H. G. Sonntag, An Introduction to General Microbiology-A Practical Approach, 2nd edition, 1991.

[34] D. Venkatesan, C. M. Karrunakarn, S. Selva Kumar, and P. T. Palani Swamy, "Identification of phytochemical constituents of Aegle marmelos responsible for antimicrobial activity against selected pathogenic organisms," Ethnobotanical Leaflets, vol. 13, pp. 1362-1372, 2009.

[35] S. Kothari, V. Mishra, S. Bharat, and S. D. Tonpay, "Antimicrobial activity and phytochemical screening of serial extracts from leaves of Aegle marmelos (Linn.)," Acta Poloniae Pharmaceutica, vol. 68, no. 5, pp. 687-692, 2011.

[36] R. Dhandapani and B. Sabna, "Phytochemical constituents of some Indian medicinal plants," Ancient Science of Life, vol. 27, no. 4, pp. 1-8, 2008.

[37] R. P. Rastogi and B. N. Mehrotra, "Ancient-modern concordance in Ayurvedic plants," in Compendium of Indian Medicinal Plants, R. P. Rastogi, Ed., vol. 3, Central Drug Research Institute, Lucknow, India; Information Directorate, New Delhi, India, 1993.

[38] J. A. Duke, Handbook of Biologically Active Phytochemicals and Their Activities, CRC Press, 1992.

[39] V. Mohan, A. G. Molly, and A. N. Eldo, "Aegle marmelos extract as a potent bactericide," Asian Journal of Microbiology, Biotechnology and Environmental Sciences, vol. 7, no. 4, pp. 639644, 2005.

[40] D. Supriya, S. Ashish, S. Ankit, G. Nirmala, and R. C. Agrawal, "Evaluation of in vitro antibacterial potential of ripe fruits of Aegle marmelos," International Journal of Pharmacy and Pharmaceutical Sciences, vol. 4, no. 3, pp. 179-181, 2012.

[41] L. L. Zaika, "Spices and herbs: their antimicrobial activity and its determination," Journal of Food Safety, vol. 9, no. 2, pp. 97-118, 1988.

[42] K. Suresh, P. K. Senthilkumar, and B. Karthikeyan, "Antimicrobial activity of Aegle marmelos against clinical pathogens," Journal of Phytology, vol. 1, no. 5, pp. 323-327, 2009.

[43] G. Yismaw, B. Tessema, A. Mulu, and M. Tiruneh, "The in vitro assessment of antibacterial effect of papaya seed extract against bacterial pathogens isolated from urine, wound and stool," Ethiopian Medical Journal, vol. 46, no. 1, pp. 71-77, 2008.

[44] R. Valsaraj, P. Pushpangadan, U. W. Smitt, A. Adsersen, and U. Nyman, "Antimicrobial screening of selected medicinal plants from India," Journal of Ethnopharmacology, vol. 58, no. 2, pp. 75-83, 1997.

[45] I. Ahmad and A. Z. Beg, "Antimicrobial and phytochemical studies on 45 Indian medicinal plants against multi-drug resistant human pathogens," Journal of Ethnopharmacology, vol. 74, no. 2, pp. 113-123, 2001.

[46] S. Maji, P. Dandapat, D. Ojha et al., "In vitro antimicrobial potentialities of different solvent extracts of ethnomedicinal plants against clinically isolated human pathogens," Journal of Phytology, vol. 2, no. 4, pp. 57-64, 2010.

[47] B. Mamtha, K. Kavitha, K. K. Srinivasan, and P. G. Shivananda, "An in vitro study of the effect of Centella asiatica [Indian pennywort] on enteric pathogens," Indian Journal of Pharmacology, vol. 36, no. 1, p. 41, 2004. 
[48] R. M. Zablotowicz, R. E. Hoagland, and S. C. Wagner, "Effect of saponins on the growth and activity of rhizosphere bacteria," Advances in Experimental Medicine and Biology, vol. 405, pp. 83-95, 1996.

[49] N. E. Hemandez, M. L. Tereschuk, and L. R. Abdala, "Antimicrobial activity of flavonoids in medicinal plants from Tafí del Valle (Tucumán, Argentina)," Journal of Ethnopharmacology, vol. 73, no. 1-2, pp. 317-322, 2000.

[50] C. Marjorie, "Plant products as antimicrobial agents," Clinical Microbiology Reviews, vol. 12, no. 4, pp. 564-582, 1999.

[51] R. F. Epand, P. B. Savage, and R. M. Epand, "Bacterial lipid composition and the antimicrobial efficacy of cationic steroid compounds (Ceragenins)," Biochimica et Biophysica Acta: Biomembranes, vol. 1768, no. 10, pp. 2500-2509, 2007.

[52] V. Bharathy, B. Maria Sumathy, and F. Uthayakumari, "Determination of phytocomponents by GC-MS in leaves of Jatropha gossypifolia L.", Science Research Reporter, vol. 2, no. 3, pp. 286290, 2012.

[53] N. Togashi, A. Shiraishi, M. Nishizaka et al., "Antibacterial activity of long-chain fatty alcohols against Staphylococcus aureus," Molecules, vol. 12, no. 2, pp. 139-148, 2007.

[54] P. Turcotte and S. A. Saheb, "Antimicrobial activity of phenolic antioxidants," Canadian Journal of Microbiology, vol. 24, no. 11, pp. 1306-1320, 1978.

[55] M. Sova, "Antioxidant and antimicrobial activities of cinnamic acid derivatives," Mini Reviews in Medicinal Chemistry, vol. 12, no. 8, pp. 749-767, 2012.

[56] V. Moorthy and M. Boominathan, "The antimicrobial activities of crude extracts and fraction of Psidium guajava and Azadirachta indica against Staphylococcus aureus in chronic disease affected patients," International Journal of Universal Pharmacy and Life Sciences, vol. 1, no. 2, pp. 2249-6793, 2011.

[57] D. Hamdan, M. Z. El-Readi, A. Tahrani et al., "Secondary metabolites of ponderosa lemon (Citrus pyriformis) and their antioxidant, anti-inflammatory, and cytotoxic activities," Zeitschrift fur Naturforschung C, vol. 66, no. 7-8, pp. 385-393, 2011.

[58] V. M. Navarro-García, J. Luna-Herrera, M. G. Rojas-Bribiesca, P. Álvarez-Fitz, and M. Y. Ríos, "Antibacterial activity of aristolochia brevipes against multidrug-resistant Mycobacterium tuberculosis," Molecules, vol. 16, no. 9, pp. 7357-7364, 2011.

[59] A. E. Nugroho, S. Riyanto, M. A. Sukari, and K. Maeyama, "Anti-allergic effects of Marmin, a coumarine isolated from Aegle marmelos Correa: in vitro study," International Journal of Phytomedicine, vol. 3, no. 1, pp. 84-97, 2011.

[60] P. P. Ram, G. Varun, S. Balram, C. Deepak, R. Veerma, and B. Anil, "Extraction and isolation of marmelosin from Aegle marmelos, synthesis and evaluation of their derivative as antidiabetic agent," Der Pharmacia Lettre, vol. 4, no. 4, pp. 10851092, 2012.

[61] A. E. Nugroho, S. Riyanto, M. A. Sukari, and K. Maeyama, "Effects of aegeline, a main alkaloid of Aegle marmelos Correa leaves, on the histamine release from mast cells," Pakistan Journal of Pharmaceutical Sciences, vol. 24, no. 3, pp. 359-367, 2011.

[62] C. P. Kala, "Ethnobotany and ethnoconservation of Aegle marmelos (L.) Correa," Indian Journal of Traditional Knowledge, vol. 5 , no. 4 , pp. 537-540, 2006. 

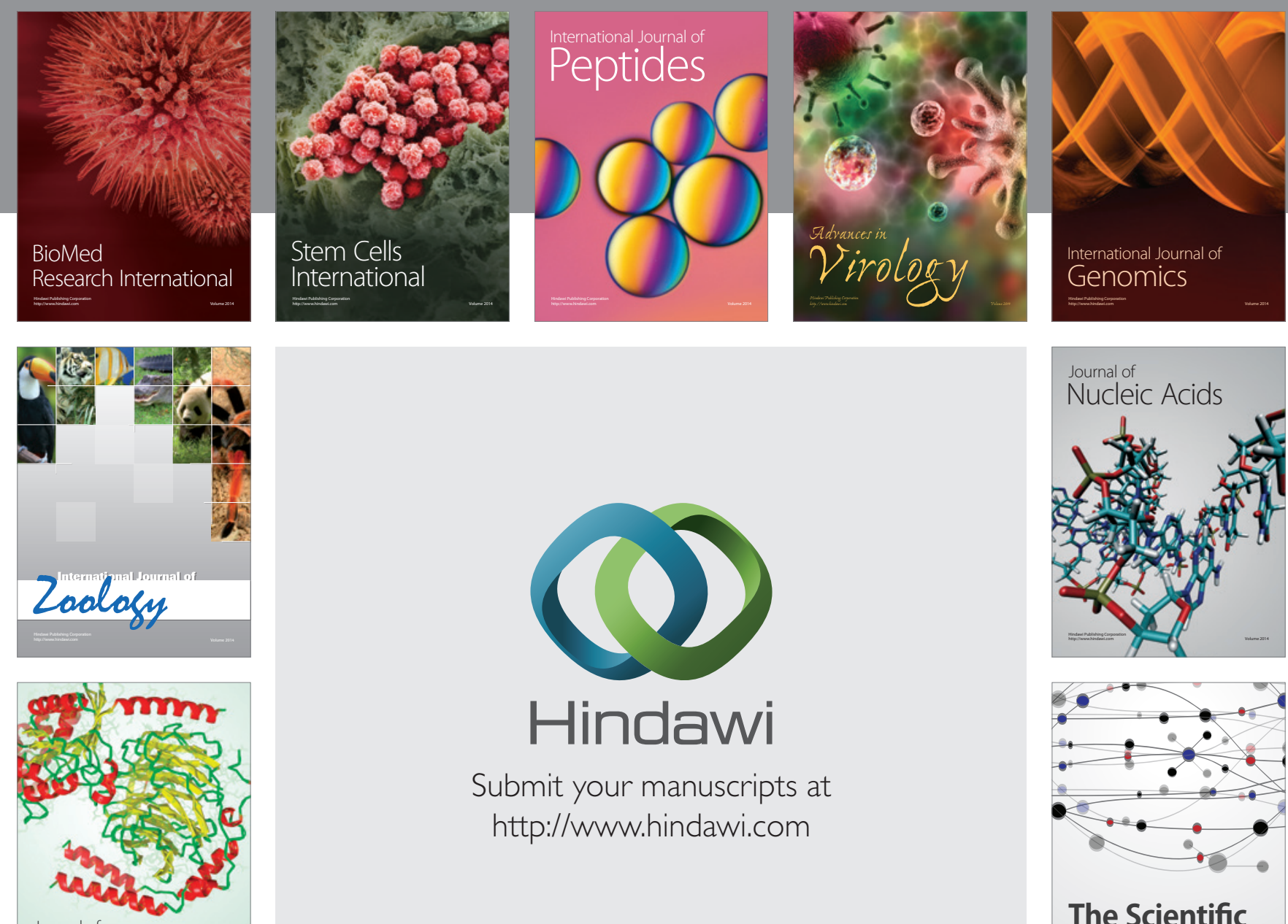

Submit your manuscripts at

http://www.hindawi.com

Journal of
Signal Transduction
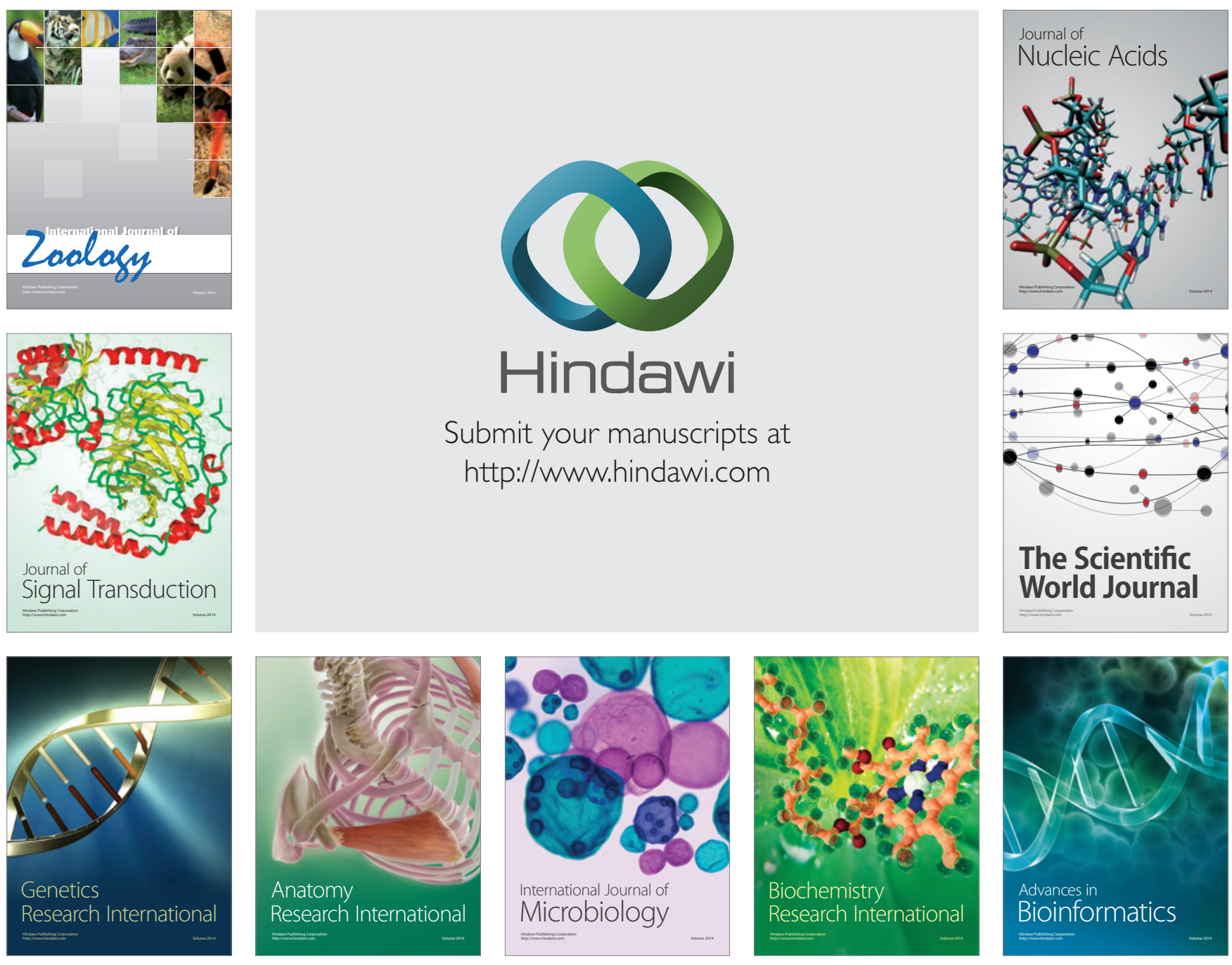

The Scientific World Journal
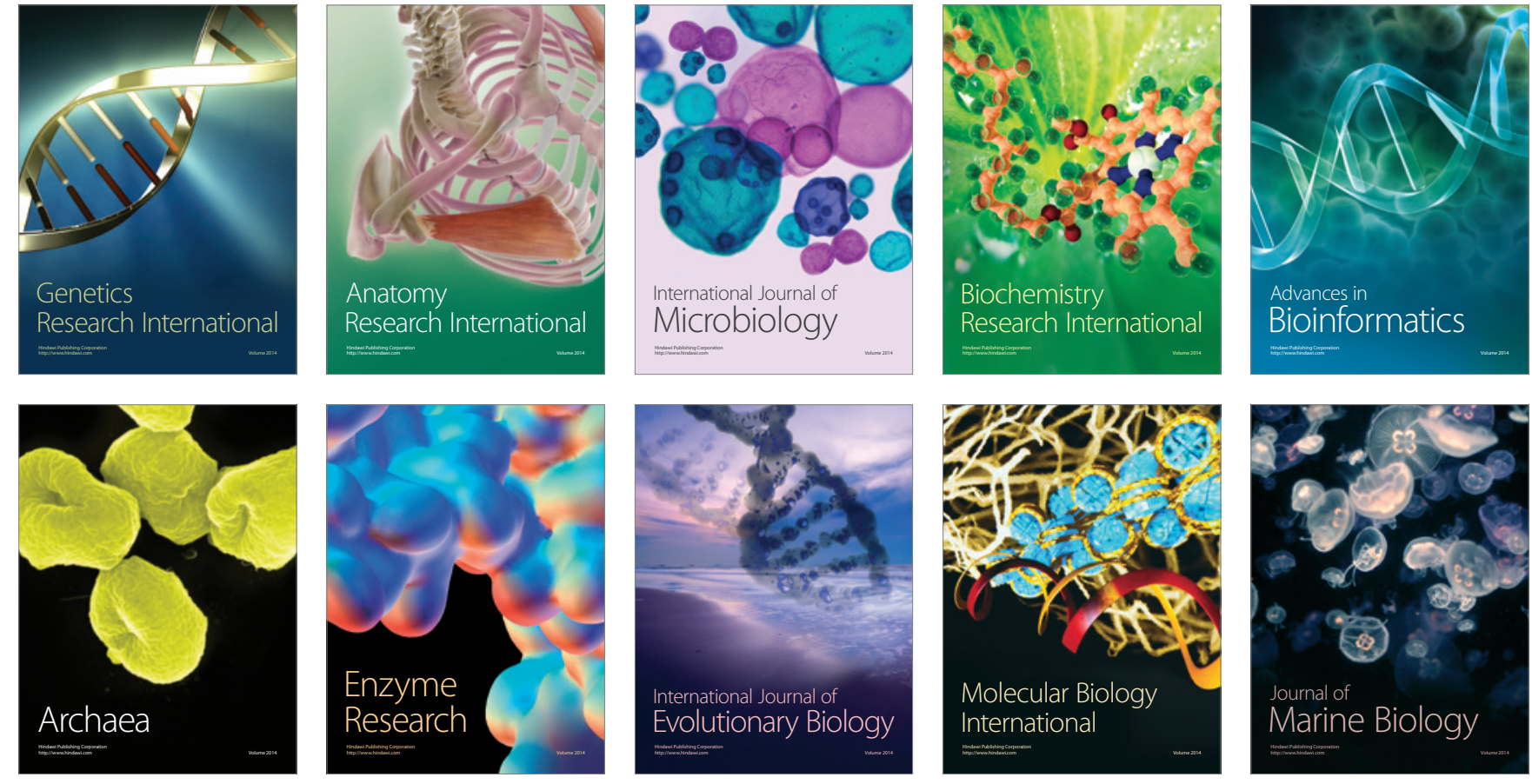